\title{
SIX NEW HILL LETTERS
}

\author{
by
}

\section{G. S. ROUSSEAU*}

SIR JOHN HILL (1714-1775), the mid-Georgian entrepreneur, man of letters and science, must have written at least ten times the approximately two hundred letters that survive. ${ }^{1}$ Disappearance of the other nine-tenths is not mysterious: Hill was vilified by most of his contemporaries, who enjoyed little, if any, sense that the documents pertaining to his life could ever be of any interest to posterity. With a few exceptions, most of Hill's extant letters were written to his patrons, the powerful Whig lords now clearly associated with mid-Georgian England: the Dukes of Newcastle, Northumberland, Devonshire, and Richmond, as well as Hill's most loyal patron, Lord Bute, George III's Prime Minister, and lesser aristocrats whom these lords attracted to their spacious country seats and elegant town houses. The librarians or archivists of these influential lords naturally retained most of the documents in their possession, and Hill's letters, whether deemed important or not, survived in this way. But a far greater percentage of Hill's letters were sent to non-aristocrats - to booksellers in Grub Street and the provinces and to members of his family - and these must have constituted the more interesting aspect of his correspondence for any future biographers. ${ }^{2}$ Yet precisely this body of his writing is lost, perhaps for ever. ${ }^{3}$ As a consequence, the portrait of Hill-the-man that has emerged derives in large part from letters soliciting favours from well-known political figures and scientists; who included, as well as the noblemen just mentioned, a host of distinguished figures: Peter Collinson, the naturalist; Emanuel Mendes da Costa, the Jewish Secretary of the Royal Society; Martin Folkes, the President of the Royal Society at mid-century; David Garrick, the famous actor and producer; Albrecht von Haller, the brilliant professor and natural scientist at Göttingen; Carl Linnaeus, the Swedish taxonomist and botanist. ${ }^{4}$

${ }^{*}$ G. S. Rousseau, PhD, Professor of English and Eighteenth-Century Studies, University of California, Rolfe Hall 2225, Los Angeles, California 90024, USA.

' Now published and annotated in G. S. Rousseau, The letters and papers of Sir John Hill, New York, AMS Press, 1982. Henceforth cited as Rousseau, Hill letters. The letters printed below follow the same editorial procedures described in Rousseau, Hill letters.

${ }^{2}$ More interesting because it would have revealed the conditions of Hill's daily routine and provided facts and figures that may now for ever be lost. As Hill's biographer, I can state with authority what the loss of these documents entails for the recovery of a full picture of the man: almost nothing substantive is known about his childhood, little is understood about his connexion with the booksellers and publishers of Fleet Street (the vast Grub Street world) once Hill assumed the throne of - in the words of Fielding and Smart duncery, and very little has been recovered about Hill's family. Hill's "Inspector" columns in the Daily Advertiser do, of course, provide some biographical information.

${ }^{3}$ An exhaustive search conducted since 1966 has failed to produce many personal letters to family members, friends, and non-scientific correspondents, but it is hoped that letters to printers and booksellers may still come to light.

${ }^{4}$ For the texts of these letters to public figures, patrons, and scientists, see Rousseau, Hill letters, passim. 


\section{G.S. Rousseau}

Because so many letters are apparently lost and because only two hundred survive, the appearance of six new letters is a cause of interest. These new letters do not radically alter any aspect of the profile of Hill-the-man, either as man-of-letters or man-of-science, nor do they shed much light on his personal or domestic situation, ${ }^{5}$ but once and for ever they resolve doubts about the notorious quarrel with Garrick, so prominently discussed in the theatre season of $1758-59$, and they demonstrate, once again, Hill's unusual method of reaching out for public posts and sometimes obtaining them. Four of the letters are written to Northumberland, the other two to Garrick. The ones to the former demonstrate an ease and familiarity between the men that is difficult to understand at this distance in time and as a consequence of the disappearance of other similar letters from Hill to his patrons. It is also difficult because no letters survive from Northumberland to Hill (can there have been none?). The modern student repeatedly asks himself why Northumberland evidently continued to be interested in Hill. Northumberland was, of course, a patron of the arts and sciences, and he must have been gratified by Hill's dedication of books to him. $\mathrm{He}$ was also related to Lord Bute, Hill's most enduring patron (Northumberland and Bute became in-laws when their children married). But not even the ambitious, outrageous Hill would have continued to solicit favours from this influential aristocrat had favours not occasionally been granted. ${ }^{6}$ Seven letters to Northumberland were extant before the discovery of these four. The existence now of eleven letters from Hill to Northumberland makes it possible to reconstruct a picture of the relation of patron and recipient that probably bears a strong resemblance to historical truth.

The relation of Hill and Garrick is altogether different. Much is already known about their friendships and quarrels, their loves and hates (as early as 1742, Hill was wooing Margaret Woffington, the beautiful young actress who was then a mistress of Garrick's), owing to the efforts of several meticulous Garrick biographers in this century, ${ }^{7}$ as well as to a superb three-volume edition of Garrick's letters. ${ }^{8}$ Even so, the entanglement in 1758-59 over a charity production of Hill's burletta The rout has remained something of a puzzle to historians of the theatre as well as more general students of the period. The outline of events is simple enough: in typical aggressive fashion, Hill approached Garrick about production, flattered his ego, cultivated his accepted generosity, and somehow persuaded him to produce and then to act the lead role in The rout in benefit performances for infirm paupers at the Lying-In Hospital in

\footnotetext{
'E.g., his family relations, private habits and customs, philosophic and metaphysical beliefs, religion, etc., but they do shed light on his health and financial circumstances towards the end of his life.

- It was to Northumberland that Hill turned when he sought election to the Royal Society and the Society for the Encouragement of Arts, Manufactures and Commerce, when the librarianship of the newly formed British Museum fell vacant (Northumberland was a trustee), and, as in this new group of letters, when a post of superintendant of the spacious gardens surrounding Kensington Palace needed to be created. Northumberland proposed Hill's name for these and other posts; see, for example, unpublished "Minutes of the Society for the Encouragement of Arts, Manufactures and Commerce", 10 March 1762: "Not elected: Dr John Hill of Bayswater ... [proposed] by the Earl of Northumberland."

'See M. Perrin, David Garrick homme de theatre, 2 vols., Paris, 1977, and especially the excellent recent biography by George Winchester Stone and G. M. Kahrl, David Garrick: a critical biography, Carbondale, Southern Illinois University Press, 1979.

D. M. Little and G. M. Kahrl (editors), The letters of David Garrick, 3 vols., Cambridge, Mass., Harvard University Press, 1963.
} 


\section{Six new Hill letters}

Lambeth on the south side of the Thames; arrangements were completed and all details seem to have been sorted out until Hill's ulterior motive - financial gain for himself - was revealed, upon which Garrick suddenly broke off communication and refused to continue.' But the psychological factors and motives involved have been uncertain. Garrick's correspondence with Hill suddenly breaks off in the midst of negotiations, and the extant letters between the two men are additionally problematic because they are all undated. ${ }^{10}$ But now, with the new letters, the matter can be resolved: Hill may have wanted to "break into the sock" but his ulterior motive was personal financial gain. As soon as Garrick realized this obviously appalling reason, he denounced Hill and backed away, never again wishing to have anything to do with him. Hill's future biographers must ask why Hill was so insanely guided by financial concern in all these transactions. That is a question that cannot be addressed here. But there is no doubt that the two new letters add to the biographies of both Hill and Garrick - to the ambition of the one and the generosity of the other - even if they strengthen an already clear image of each figure.

All six letters are housed in the Perceval Collection of Manuscripts in the Fitzwilliam Museum of Cambridge University. This huge assortment of varied manuscripts was donated by Spencer Perceval (1762-1812), the English prime minister who was murdered in the lobby of the House of Commons by a lunatic

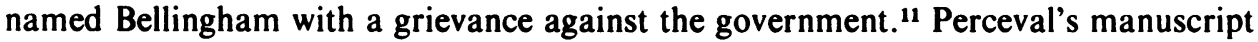
collection seems to have remained intact in the early nineteenth century and was kept in the private hands of the family. Perceval's grandson, Sir Spencer Walpole, KCB (1839-1907), retained some of these manuscripts while he was composing his maternal grandfather's biography: The life of the Right Hon. Spencer Perceval, including his correspondence with numerous distinguished persons (London, 1874). After Walpole's death in 1907, the family donated the entire collection of Perceval family papers to the Fitzwilliam Museum, where they have since been known as "the Perceval Bequest". The choice of final place was not strange: Perceval was educated at Trinity College, Cambridge, and remained loyal to his alma mater throughout his life. ${ }^{12}$ It is not altogether clear why these six letters, having nothing to do with the government or the Perceval family, are included in the group. ${ }^{13}$ On the other hand, Spencer Perceval is known to have bought up collections of papers in his own lifetime, ${ }^{14}$ and the Perceval Bequest includes dozens of manuscripts which have no connexion with the Perceval family or its fortunes in British public life. All that can be known for certain is that Hill's letters were part of this collection in the nineteenth century and that they came to the Fitzwilliam Museum in the early twentieth century

\footnotetext{
- See Rousseau, Hill letters, item 92.

10 Ibid., items 86, 89-90, 99.

"See [anon.], A full report of the trial of John Bellingham for the murder of the Right Hon. S. Perceval, London, 1812.

${ }^{12}$ For his loyalty to Cambridge, see $A$ funeral discourse ... on the death of Spencer Perceval, London, 1812, a copy of which is in the British Library.

${ }^{13}$ There is no discussion of these letters in any of the secondary material dealing with Spencer I have had an opportunity to examine.

14 See Spencer Walpole, The life of . . Spencer Perceval, including his correspondence, London, 1874, 2 vols., vol. 1, p. xi.
} 


\section{G. S. Rousseau}

with the rest of the Perceval Bequest. ${ }^{15}$

The letters were unknown to me while I was compiling my edition of The letters and papers of Sir John Hill (1982). Owing to the generosity of the current Keeper of Manuscripts at the Fitzwilliam, Dr Paul Woudhuysen, and to the kindness of his staff, I am able to print them for the first time. They are published by permission of the Syndics of the Fitzwilliam Museum.

\section{LETTER 1}

To the Duke of Northumberland ${ }^{16}$

Arlington Street, 9 June 1767

My Lord

I heard with great Sorrow, at my Lord Butes ${ }^{17}$ yesterday, that your Grace was very ill of the Gout. I hope it is better; and heartily wish your Grace woud be pleasd to be as well as I am, which certainly woud be, by the use of the same means. My Lord Bute was pleasd to shew me the very white Soap of wax; ${ }^{18}$ in the making of which your grace had succeeded so very far beyond Mr. Fordyes ${ }^{19}$ whom my Lord Bute emplyd to make some. Lord Bute is curious to know what colours can be usd with it; I fear none that have had anything acid in their preparation. but I am proposing to by several kinds; and by Leave to ask your Grace for a small piece of it for that purpose. I have the Honour to be with the greatest Respect and Gratitude

$$
\begin{aligned}
& \text { my Lord } \\
& \text { your Graces } \\
& \text { most humble } \\
& \text { and most obedient Servant } \\
& \text { John Hill }
\end{aligned}
$$

Address: to Lord Northumberland at his House in Charing Cross Source: The Fitzwilliam Museum, University of Cambridge, Perceval MSS K 27.

\section{LETTER 2}

St. James's Street, 4 Feb. 1773

To the Duke of Northumberland

My Lord Duke

There is a Charity your Grace protects, which wants at this time the Might and Influence of your Graces name, to save it from Destruction. The Lock Hospital ${ }^{20}$ is

\footnotetext{
is Fifteen years before the Perceval Bequest came to the Fitzwilliam in 1910, M. R. James compiled $A$ descriptive catalogue of the manuscripts in the Fitzwilliam Museum, (Cambridge University Press, 1895), which does not mention any Hill letters as already in the Fitzwilliam or, of course, the Perceval collection.

${ }^{16}$ Sir Hugh Percy (1715-1786), 1st Duke of Northumberland of the third creation, 2nd Earl of Northumberland, FRS (1736), and, after Bute, one of Hill's most loyal patrons.

17 At the London residence of John Stuart, Earl of Bute, where Hill and Bute often collaborated on The vegetable system (1759-75) which Bute had patronized since its inception. Bute, referred to by his contemporaries as the "Maecenas of Botany", was a keen botanist and gardener and relied on Hill for many types of horticultural assistance. Hill had heard a great deal about Northumberland at Bute's house.

1s A type of honey-wax. Hill had been interested in its production at least since 1759 when he referred to its curative powers in The virtues of honey in preventing many of the worst disorders, London, M. Cooper, 1759. He thought it would assist Northumberland in his latest bout of illness.

19 George Fordyce, one of Bute's gardeners.
} 
going to be converted from its Original Purpose, to a Methodist Meeting House; the Chapel is to be enlargd at the Expence of the House. Mr Bromfield, ${ }^{21}$ who stated this matter to me, requested me to ask your Graces permission that he might relate the whole to your Grace; and that you woud give him Leave to wait on your Grace a moment for that Purpose. He wishes your Grace also woud honour them 22 by anything at the disposition of your Lordship. I know I need not apologize to your Grace for asking you to do a publick good, and beg the honour of a Line from your grace to tell me whether Mr Bromfield may be permitted to wait on your Grace, and if he may at what hour

I have the honour to be with the most perfect Respect

My Lord Duke

Your Graces

most humble

and most obedient Servant

John Hill

Address: to Lord Northumberland at his House in Charing Cross

Source: The Fitzwilliam Museum, University of Cambridge, Perceval MSS K 28.

\begin{abstract}
${ }^{20}$ A charity hospital for the treatment of venereal disease founded in 1747 , located in the present Grosvenor Place and not to be confused with the hospital for lepers in Southwark called by the same name; see D. Lysons, London and its environs, 8 vols., London, 1761, vol. 3, p. 326; and H. B. Wheatley, London past and present, 3 vols., London, 1891, vol. 2, p. 412. The Duke of Northumberland served with others on a board of trustees, but the real control of the hospital was in the hands of two men: Martin Madan (1726-1790), its chaplain, and William Bromfield (1712-1792), its medical officer. See note 21.

${ }^{21}$ The surgeon mentioned in note 20 who had been an acquaintance of Hill's since 1757 when they pooled their ideas on the qualities and habits of English nightshade plants. Hill's account in this letter is oblique and elliptical and does not grasp the dilemma Bromfield faced at the Lock. Originally a lawyer, Madan had converted to Methodism in 1750. Afterwards, he was in close touch with Wesley and the Countess of Huntingdon (of the religious "Connection") and became one of London's mid-eighteenth-century popular preachers. The Lock Hospital proved to be Madan's chief pulpit. Crowds from all over thronged to the hospital to hear his sermons, and by the late 1760 s, funds donated to his recitals proved to be the hospital's chief source of income. Eleven years before Hill's letter was written - in March 1762 - a new chapel was built by the governors of the hospital to accommodate the overflow crowds. Yet not even this new chapel could contain them, and eventually the governors agreed to erect another enlargement. According to the rate books of the Lock Hospital (Westminster Parish Archives, 1760-1773), there was no debate about the construction among the governors and staff members. The minute books of the governors of the Lock Hospital, now housed in the Royal College of Surgeons of England, may throw further light on this matter. Even Bromfield, Madan's co-administrator at the Lock and no Methodist, realized that Madan's popular performances were keeping the charity hospital solvent. And if diaries of the period are trustworthy about the Methodist preacher's popularity, he must have been one of the most sought-after speakers of the times. But Hill, ever attentive to possibilities for professional advancement, realized what a rare opportunity existed here. He had been on good terms with Bromfield for over a decade and had hoped that Bute's patronage (after 1762, when he was appointed Prime Minister) would further advance his cause. In 1761, Bromfield was appointed Surgeon to Her Majesty's Household after the marriage of Charlotte, Princess of Mecklenburgh, and George III. With at least two patrons at court - Bromfield and Bute - Hill hoped he could be further advanced. And then there was the desired intervention of Northumberland, which might somehow involve Hill. If Hill were lucky, a post might be created for him. This possibility for professional advancement rather than any charitable or religious consideration motivated Hill to send the letter and collaborate with Bromfield. But there is no evidence that Bromfield was willing to advance Hill's cause or that Northumberland granted Bromfield a hearing or intervened. For further information about Bromfield, see George C. Peachey, William Bromfield, 1713-1792, reprinted from Proc. R. Soc. Med., London, 1915.

22 Not the staff and governors of the Lock Hospital but Bromfield's visiting delegation.
\end{abstract}




\section{G.S. Rousseau}

\section{LETTER 3}

St. James's Street Fryday Oct. $1768^{23}$

To the Duke of Northumberland

Sir T. Robinson ${ }^{24}$ tells me your Grace thinks of the great attendance, requird from a President of the Royal Society: but that is less than it may appear.

I can assure your Grace there is nothing the Society desires so much as that you shoud be president: and that no opposition whatever woud be made to it. I am also certain that Lord Charles Cavendish ${ }^{25}$ woud not, if they desird it, be their President; for his own particular Reasons. I also know that, in a political Light, the Matter is worth your Grace's thought; for the President naturaly has a great and fair Influence with the numerous important Members. As to the Duty, your Grace woud have four Vice presidents of your own appointing; and that for the Season of their Meetings if your Grace were there one Evening in three or four it woud be sufficient. Tis for the better Part of the Societys Sake I wish your Grace at their head;26 for some of them

${ }^{23}$ No date appears on the manuscript. Although written five years before the previous letter, it is printed here in succession to reflect the order of the Perceval Manuscripts. Included as part of this manuscript known as "Perceval K 29" are two printed but undated broadsides, one entitled "Medicines sold by H. Turpin, Bookseller and Stationer, at the Golden Key, St. John's Street, near Hicks's Hall, West-Smithfield, Lond," which lists all sorts of books and paper supplies as well as twelve of Hill's medicines ("balsam of honey at 3s, per bottle, essence of water dock at 3s, elixir of bardana at 3s, tincture of centaury at 3s, tincture of sage at 3s, tincture of valerian $2 \mathrm{~s} 6 \mathrm{~d}$, tincture of spleenwort $3 \mathrm{~s}$, tincture of agrimony $3 \mathrm{~s}$, volatile Spirit of Feverfew 3s, per bottle, Carline tincture 3s, Essence of Restharrow 3s, Veronica or speedwell Drops 3s") and the other, a four-page (quarto) printed pamphlet, untitled and undated but paginated, describing a "lately printed household book of an old earl of that [Northumberland] family" concerning the finances of estate-planning and keeping servants at the duke's various seats, with particular references to pages in a "printed book". The pamphlet cannot have been written by Hill, since the document is critical of "the whole expence of the [present] earl's family" which is "managed with an exactness that is very rigid, and seems even somewhat niggardly" (p. 1). Criticism of Northumberland, the one man who may have become his primary patron when Bute abandoned him and left Britain for the Continent, was the furthest thing from Hill's intentions in October 1768.

${ }^{24}$ Sir Thomas Robinson (1700?-1777), the wealthy aristocrat and spendthrift who financially ruined himself, migrated to Barbados, later returned to London and ruined himself a second time. Hill had certainly heard about him and possibly even met him in the early 1740s while he (Hill) was in the employ of the Duke of Richmond and a resident of Goodwood House in Sussex; see Rousseau, Hill letters, pp. 5-7, where Robinson's relation to the intellectual and theatrical circle at Goodwood is discussed. No doubt Hill and Robinson continued to be in touch after the latter returned to England early in 1747. Once back on native soil, Robinson acquired the largest number of private shares in Ranelagh Gardens, the place of amusement much frequented by $\mathrm{Hill}$, and became a leading dilettante and person of high fashion.

${ }^{25}$ Third son of the second Duke of Devonshire by Lady Anne Grey, and father of the distinguished natural philosopher Henry Cavendish. Charles, FRS, a patron of science and former member of the Council of the Royal Society, was not a candidate for the presidency. The President, Lord Morton, had died on 12 October and Sir James Barrow was elected on 27 October to act in his place until the anniversary of the Society on 28 November. Hill's letter was therefore probably written some time between 12-27 October. On 28 November, the Fellows elected James West, an antiquary who had been Treasurer since 1736. Northumberland was considered but was unsuccessful.

${ }^{26}$ Hill may have believed what he wrote here but ultimately his wish was for his own preferment. His relation to the Royal Society had been problematic from the mid-1740s, when its Fellows first courted him and then refused in 1750 to elect him a Fellow. In retaliation, Hill published one attack after another: Lucina sine concubitu. A letter humbly address'd to the Royal Society (1750); A dissertation on Royal Societies (1750); A review of the works of the Royal Society (1751); and the "Inspector" columns of the Daily Advertiser (1751-52), which abound with comments about the Society. Yet Hill's attitude was not merely destructive: his mind was permeated with constructive suggestions and he continued to wish good for the Royal Society throughout his lifetime. It was a complex attitude of love and hate that makes it all the more difficult to evaluate letters such as these to his patrons. 


\section{Six new Hill letters}

have no right to any good wishes from me: but many desire the honour ${ }^{27}$ and I should be very happy to see them obtain it.

I have the honour to be My Lord

Your Graces

most humble

and most obedient Servant

Address: none

Source: The Fitzwilliam Museum, Cambridge University, Perceval MSS K 29.

\section{LETTER 4}

To the Duke of Northumberland

My Lord Duke

$\mathrm{Mr}$ Worsley ${ }^{29}$ has been so obliging to promise me to set right my Distress at Bayswater; ${ }^{30}$ by enlarging the Passages in the King's Garden at Kensington, which is indeed as needful for his Majesty's Service as my Security; because the Canal is now choaked up in the garden. ${ }^{31}$ but Mr Worsley tells me it is necessary there shoud be an order from the Treasury, which I am to obtain by Petition. I am also told that, little good is to be expected from that Application, unless I previously apply to the Duke of Grafton; ${ }^{32}$ acquainting his Grace with the nature of the Case; and requesting his Protection. I have not the honour to be known to the Duke of Grafton. I therefore presume to request of your Grace the honour of introducing me to him, at his Leave, or by a Letter that I may take to him, or any other way, which your Grace (who know these things as perfectly as I am perfectly ignorant of them) may think best.

\footnotetext{
${ }^{27}$ It is difficult to ascertain whether Hill designates any particular Fellow by this remark. He certainly remained on amicable terms with some of the Fellows, especially naturalists and botanists, and it may be that at least some of them encouraged Hill to remain informally associated with the Society. By "honour", Hill denotes his own good wishes rather than those of Northumberland who would further bestow greatness on the Society by accepting the presidency. This concluding sentence epitomizes Hill's complex attitude outlined in note 26 .

20 The date given in the Fitzwilliam Catalogue as merely October is incorrect, as careful scrutiny of the handwriting reveals. The letter says December.

29 Robert Worsley, a Clerk of the Works at Kensington Palace.

${ }^{30}$ Hill's financial situation continued to deteriorate after 1759, when he began serious work on The vegetable system and bought property and a house in Bayswater (see Rousseau, Hill letters, xxx-xxxi). By 1767 , his situation had worsened considerably as a result of fewer annual publications and compilations, and he cast about to find employment that would ameliorate the financial situation. His six children were growing up, his wife's fortune gone, and he had many mouths to feed. Even the sale of herbs at Bayswater was less profitable than he had anticipated.

31 The Serpentine, east of the Palace, had overflowed through heavy rain into the walkways of the King's Garden. Hill had spent time in the Palace and its gardens with Bute and the King and was on familiar terms with the staff. In 1760, Bute saw to it that Hill was appointed master-gardener there at $£ 2000$ per annum; see Horace Walpole to Henry Zouch, 3 January 1761, The correspondence of Horace Walpole, New Haven Conn., Yale University Press, 1970, vol. 14, p. 42 and Gentleman's Magazine, December 1760, 30: 595. It is not clear how long Hill retained this post.

${ }^{32}$ Augustus Henry Fitzroy (1735-1811), third Duke of Grafton and since 1767 the effective head of the Chatham ministry. He was on good terms with Northumberland at this time and serving in the government with him.
} 


\section{G.S. Rousseau}

I beg your Graces Indulgence to pardon this Application, on which no less than the fortune I had saved for my children is at stake. ${ }^{33}$

I have the honour to be with the most perfect Respect and Gratitude

My Lord Duke

Your Grace

most humble and most obedient

Servant

John Hill

Address: none

Source: Fitzwilliam Museum, Cambridge University, Perceval MSS K 30.

\section{LETTER 5}

Bayswater Saturday [early December 1758] ${ }^{34}$

\section{To David Garrick}

Sir

Give me Leave to thank you for a great Civility. I am very sensible of it; and very much obligd. As to the Line in the Burletta: ${ }^{35}$ I am quite of your opinion that there is nothing disrespectfull in it; and that, as to the Sale of the Medicines, ${ }^{36}$ it woud tend to increase, rather than diminish it, but there are quite other Considerations in the way. I have no desire they shoud be spoken of at all, otherwise than in the immediate way of their disposal. I publish those things, because I must provide for my Children; ${ }^{37}$ but the whole matter is very far from being agreeable to me. You can easily put a line in

\footnotetext{
${ }^{33}$ Part truth, part deception. Hill had actually amassed little money, being unable to save and always living in high style. When he died in 1775, he left his wife and children less than one would expect from this remark; see Rousseau, Hill letters, pp. 186-190, for the actual figures.

${ }^{34}$ The letter is undated except for "Saturday" but its internal contents permit it to be dated with reasonable accuracy. It was certainly composed after item 92 in Rousseau, Hill letters, which it possibly answers, and before The rout was performed in mid-December for the Christmas benefit at the Lying-In Hospital in York Road, Lambeth.

${ }^{35}$ I.e., the farce Hill wrote and called The rout. This letter cannot be attributed to the year 1754 when Hill had composed another burletta, The maiden whim; or the critical minute, a farce, because this letter was written from "Bayswater" into which property Hill did not actually move until late 1758. The conflict over The rout is more complicated than is suggested by this letter when removed from its context or by the group of related letters in Rousseau, Hill letters (89-92, 95, 99-100). Some time in the autumn of 1758, Hill wrote to Garrick stating that he had written a farce that he would like to have acted during the 1758-59 season. Garrick replied politely and asked to see the text. Further correspondence ensued and the two men, who had known each other for a long time, may even have met. By late November, a date was set for several performances but somehow Hill revealed that he hoped to raise cash for himself and his family. Garrick then changed his mind. But this letter was composed before Garrick vacillated and while the two men were still contemplating performance. The reference here to "the Sale of Medicines" is to a line Hill hoped to alter but which remains in the printed version.

${ }^{36}$ Hill had suggested to Garrick that his herbal preparations should be available for sale at the Christmas benefit. Garrick pointed out (in a letter that does not survive) that such practice was unusual and, moreover, inappropriate. Hill argued, in person or by letter, that the availability of these medicines would increase profit for the hospital. In the margins accompanying these lines Garrick has written in his own hand, "a remuneration". This lends further weight to the theory that Hill's private motive of gain changed Garrick's mind about producing the burletta.

${ }^{37}$ Hill's repeated excuse to legitimize his profit-seeking motives. By "publish those things" Hill meant that he manufactured medicines and advertised them.
} 
its place; ${ }^{38}$ and the Burletta will not suffer by it. I therefore request it of you. Why shoud the world think you and I are upon ill terms together ${ }^{39}$ - you are so obliging to think some Respect is due to me; infinit belongs to you as the first man in all the world in your Profession. It is allmost being too wise about a trifle, to say it here, but tis Certain that men of Talents would have twenty times the Respect they meet from the world, if they woud shew more to one another. ${ }^{40}$

I am sir your very obedient Servant

Jddress: none
Source: Fitzwilliam Museum, Cambridge University, Perceval MSS J 41. ${ }^{41}$

\title{
LETTER 6
}

\section{To David Garrick}

Sir

I beg you at the bottom of tomorrows Bills to repeat that the Rout is deferd on account of the Indisposition of one of the Performers. ${ }^{43}$

I believe the sale of the Printed Books ${ }^{44}$ will be assisted by this and I am very Sensible you wish to do me Service.

\section{I am Sir \\ Your very humble Servant \\ J Hill}

\begin{abstract}
${ }^{38}$ The line in question contained a reference to these medicines, indicating that they would be available in the foyer after the show.

${ }^{39}$ The reference is baffling and it may refer to a number of possibilities. Hill and Garrick had quarrelled in 1754, and it may be the memory of that public scandal to which he refers. On the other hand, the reference may be more current: to something that had happened in late November 1758 and to which reference is made in at least one letter from Garrick to Hill. "There is a certain Air of incivility in yr last Letter", Garrick wrote to Hill (Rousseau, Hill letters, item 92) some time in late November, and continued, "I Use Every Gentleman with Justice and Good Manners, \& Expect from Dr Hill a return in Kind." The "ill terms" in Hill's letter relate to that remark.

${ }^{40}$ If this letter answers item 92 in Rousseau, Hill letters, then Hill is replying to Garrick's final closing remark about civility among gentlemen. The placing of Hill's sentence, at the close of the letter, suggests at least the possibility.

${ }^{41}$ A curator's note attached to the holograph manuscript states in handwriting: "217 Hill, a series of A. L. S. each Ip. March 1756, etc. addressed to David Garrick. 3s. each." The reference is to a sales catalogue printed in the late eighteenth century when these letters were acquired by Perceval. The date 1756 is obviously in error.

42 This letter was written after the previous one but may reply to item 92 in Rousseau, Hill letters. If it does, then the "Air of incivility" Garrick claims to have detected may include Hill's peremptory tone and apparent brevity. Whichever letter it follows in the collection of undated November-December 1758 HillGarrick letters, it is clear that Garrick had now decided not to perform the farce.

${ }^{43}$ Rather than for the genuine reason, viz. that Garrick had detected Hill's private motives and therefore changed his mind. Statements such as this one make it patent that merit had never been an issue in Garrick's decision: from the start (1740s) Garrick was well disposed towards Hill and thought well of his literary ability. He now altered his attitude for moral reasons.

4 Hill had arranged for the London house of Cooper to publish The rout. Cooper had published many of his books and was ready to print copies as soon as Hill gave him a cue. The farce was printed during the first week of December 1758 (for evidence see G. S. Rousseau, The Renaissance man in the eighteenth century, Los Angeles, California, William Andrews Clark Memorial Library, 1978, p. 123).
\end{abstract}




\section{G. S. Rousseau}

P.S. I think I have learnt some Experience about farces and beg to know whether you continue to think of the Temple of Fame, ${ }^{15}$ whether it is for this or next Season; and what woud be the advantage to me for writing the Scenes according to your Pleasure. Address: none

Source: The Fitzwilliam Museum, Cambridge University, Perceval MSS J 42.

4s Another play Hill hoped to have produced by Garrick. It was never published and no record of it exists. 